\title{
THE STREET CHILDREN FIGHT AGAINST POVERTY: A STUDY ON THE SANGGAR ALANG ALANG, A FOUNDATION IN SURABAYA THAT CARE FOR THE STREET CHILDREN TO ESCAPE POVERTY TRAP
}

\author{
Rachman AbduI*, Ujianto, Brahma Ratih Ida Aju \\ 17 Augustus 1945 University, Surabaya, Indonesia \\ *E-mail arsaymann@yahoo.com
}

\begin{abstract}
The crucial problem during centuries in this world is poverty. However, this problem needs industrious effort to overcome in various types. Poverty is the responsibility all of human being over the world, therefore in the year 2000 the United Nations Organization i.e. UNDP declared the millennium development goals to reduce half of extreme poverty by 2015 as of the first priority. A lot of efforts to overcome poverty had been done, yet those efforts were only synonymous with treating those who were sick, had not done early prevention of a kind of vaccination so that children do not experience poor life hopelessly. The research was conducted through The Sanggar Alang Alang Foundation in Surabaya, later on it is mentioned as the sanggar, a non-governmental organization (NGO) that had carried out informal education on street children, neglected children, beggars, buskers in order to have basic capital through life after starting adulthood (18 years), at least it can be expected being a member of a prosperous society, even though there is also a failure, because children are also educated by a non-conducive environment coupled with the child's personality itself also influenced the results of the studio's business. Education in the sanggar from specific content and ways of conveying, the material provided includes issues of ethics, aesthetics, norms and religion, education is free as in family gatherings. All the implementation of education is intended to complement formal education or pursue packages for assisted children who are endeavored to get scholarships and some are funded by their own foundations. Thus, in addition to the government, the community also has social responsibility in overcoming poverty and inequality by maintaining neglected children and the poor as mandated by the Law, especially as the Sanggar Alang Alang Foundation does not have a definite financial source.
\end{abstract}

\section{KEY WORDS}

Poverty, street children, empowering, strategy.

This research in poverty among the street children had been done in Surabaya, Indonesia using qualitative method with the assistance of the Sanggar Alang Alang Foundation or mentioned as the sanggar, that care for neglected children in the society, they are the street children, such as the other children lived and life in the street of the cities around the world. When economist believe that poverty comes from the insufficient capability of mankind to fulfill their needs demanded, then they have theories to overcome poverty problems, they just look at the income intensively and ultimately they made a proposal to enhance the weaknesses of the poor by giving them capital, hard skill such as technical workforce and give them access to the market.

This research found phenomenon that poverty problem in some countries prove the human role (it means nationality, race, ethnic, tribe) contribute poverty by nature, culture, and way of life.

The mission of the sanggar is to help the poor how to change their fate and giving them facility to obtain education, either formal and/or informal education. The sanggar looked for the scholarship for the children, since the elementary to the higth school, even to the university. There are two children had achieved bachelor by this effort, and more of it the children had facility to go to high school. 
The informal education given by the sanggar was suitable to the taxonomy of Bloom (1956) constitute cognitive, psychomotoric and affective, however the most important program was to change the character of the children to become strong, polite, religious and smart. However, formal school was inadequate for the whole requirement; the lack was fulfilled by the sanggar as declared to contribute in ethics, aesthetics, religion and norms. The sanggar set the rules, the children had to take bath before coming to the sanggar, they had to kiss the hand of the oldies who were in the sanggar. That is the way how to reduce the bad habit brought from the street.

One day the sanggar had some visitors, the chairman introduced his visitors to the children in the sanggar and mentioned the names of each visitor one by one. Afterward the chairman asked the name of each visitor to the children, then the children responded the question to mention exactly. The purpose of this action was to strengthen the children's memory and actually more beneficial for the children's education process in the school.

If we were in the sanggar (means gallery) we couldn't think that the children were the buskers or the dirty boys or girls, because they were wearing clean clothes with polite attitude. However those character building would not be expected in the formal school and in the children's family environment, and it could be named as a wonderful home, a home where the children and their parents felt like in a big family.

Aside from psychological training, the activities during a week was to train how to play the traditional music instruments, tradional and contemporary dance, to read Al Qur'an, the Islamic holy book, and for the children having talent in sport, the sanggar provided boxing, sport and soccer trainings, it used the public road in front of the sanggar as the gallery, when the busy traffic jams turned down. Once the sanggar on behalf of Indonesian team had performed at the international street children soccer game in Brazil.

Sometimes the sanggar operated a concert conducted by the street children, the fee obtained was distributed to the team members, while the chairman confirmed that by this concert could gain more money and more prestigious rather than busking, it seemed like the beggar. Be ashamed to be a beggar. This is the way how the sanggar brainwashing its children again and again to pursue human dignity.

The researchers interviewed eleven participants, consist of three personels of the sanggar, three poor members, three ex-buskers or street children and two poverty observers. They came from different background. Hence, we can see the representatives of the participants.

The followings are the result of interview:

$\mathrm{DH}$, the chairman and founder of the Sanggar Alang Alang, previously he was the cameraman of state owned television in Surabaya. When in 1998 he saw Surabaya City was overwhelmed with the beggars, buskers, pickpocketers and various poor people. He wanted to know about the street children primarily the buskers by approaching them who gather around the public bus-terminal. He offered to train the buskers to play guitar better, the buskers attractively responsed very well.

This is the first step without on purpose to make more serious relationship between $\mathrm{DH}$ and the buskers closer and closer. DH recommended the buskers to say "thank you" for the listeners when finishing to sing and getting the alms.

Someday the gangster in the bus-terminal threatening $\mathrm{DH}$ to quit his activities, because his activities had reduced the power of the gang to the street children exploited. DH said to the buskers that this relationship would be ended, because it had annoyed the gang, but the buskers refused this reason. They wanted to seek the other venue to meet. With the difficulties finally they found a house to rent close to the terminal.

$\mathrm{DH}$ and his wife could not escape from the commitment to help the poor, even though they have to spend most of his monthly salary, the only income they have, for the cost of rental house and the other expenditures, and they thought: so what to do.

They felt that they begun the activities by the talent of art, that mean the art could be the way to elevate poverty. By around 70 square meters of the house used, they had to gather around one hundred street children and their parents. However, it was an extraordinary difficulty. In case of insufficient space, they occupied the road for activities. 
The street children's mothers were organized in the BIAN, or mother and child guidance section of the sanggar. The reason of the sanggar to envolve these mothers as the parents of the children was they are closer to the children rather than the fathers. By envolving them would be able to participate in giving better education in their daily activities to improve the children's bad habit such as ethics, religiousity, and compliance with legal norms, while their husbands (if any) still in work.

SA, a 45-year-old woman, has three children, all of them go to school, beside their profession as buskers. SA works for her junk food merchandise, every midnight she goes to the market to buy banana, cassava, ore peanut, and others then boil these goods until dawn. In the early morning her husband brings it around the town peddling merchandise.

Previously she was illiterate, but by joining the sanggar she learned to read and write.

SL, a 45-year-old woman with highschool graduate, had three children as the buskers. Previously she was an administrator of a hotel, but to get money by busking was preferred because a lot of income and freedom. Her household was broken, her husband was hooked by someone, so she was hopeless, when we asked about her future, she shaked her head. She lived in a rental room in a slum environment of around 9 square meters together with her children, took bath in a public bathroom. By her membership of the sanggar, she got aids from the government, sometimes she got charity of the church.

She and her daughters earned money as much as equivalent $\$ 10$ to $\$ 15$ a day, a sum of more than enough to live, but she didn't have any saving, because she believed that she easily got money, the bad habit that make this guy consumed all of her earnings with no plan to improve her life. Is it poor?

Usually the poor were entangled in loan sharks, it is normal for the consumptive life style. She owned LED television, cellular phone, refrigerator and motorcycle and the other goods that could not reflect that she was poor.

$\mathrm{SM}$, a 44-year-old woman as a single parent, her husband ran away when she just two month gave birth. She lived with two kids, R (boy) and F (girl) in a terrace coffeeshop. SL didn't have any definite job. Some times she was a scavenger, beggar and part timer laundry washer.

When the researchers asked her about her plan to improve her life, she could not explain a specific plan, because she was only got elementary school.

From all of the three participants above, we know different condition of each other, even though they were classified as the poor.

The children interviewed were ex the buskers, some of the members of the sanggar still do it, usually when they were still in the elementary school, but when they go to high school this activity quit by itself.

Almost all of the street children in the world have several similarities in the way they live, free of any norms but no future hopes. That is why assistance and guidance needed for them, mentioned below is the sample of ex buskers interviewed:

GN, this boy of 17-year-old previously he was a busker, at last he could go to high school because of the role of the sanggar to get scholarship. He had talent in boxing and got championship in a tournament and playing electone organ, he preferred reggae. When the researchers asked him about his future, with his self confidence he said that he wanted strictly to become a government official.

KK, the boy of 14-year-old, he didn't have any parent, his mother passed away when he was still 4-year-old. Unfortunately, his father left him and his two siblings, and his eldest brother took over this burden to take care these boys.

His eldest brother was the member of the sanggar and after 18-year-old he left the sanggar for his age of adulthood. KK never went to school, his brothers taught him to read and write, the only earning was by busking, and the education of this boy was depended on his membership of the sanggar. He kept silent when asked about his future.

Slh, this girl a 15-year-old was an orphan, she and her three siblings were raised by her mother who work for selling snacks. Her late father died in 1988 was a taxi driver. During became a widow, this woman took care of the children and her two elder daughter were graduated from high school, and Slh the third child was in the second year of high school. 
This means even though a widow with three children, she were able to control her household. It was quite different with SM mentioned above who didn't know what to do.

Other participants involved are the observers. This part is required to triangulate the information gathered.

The two observers said that the bad cause of poverty was the poor mentality, the people who always hope the gift from others. This habit was not only influence the poor, but also the officials for the bribery.

The two different observers said the bad habit of the poor were wasteful, either personal habit brought by family habit or cultural influence. In some tribes in Indonesia there are traditional ceremonies that consume more financial expenditures.

Researcher concludes that, although poverty is an economic realm, but improving the economy is not always based only upon economic techniques. This means that the economy is not a single solution, even probably this is not a central problem of poverty, it is necessary to consider various aspects involved. Poverty must be addressed early, not after becoming severe.

There are two points of inquiry conclusion:

Human role in poverty trap. The evidence illustrate above show us that eliminate poverty would be more essential to begin from the human side, even though it was recognized that the poverty was economic problem, but it might not be overcame by economic instruments.

Start from the requirement of life, it was not only physical matter. As theorized by Maslow (1987) about hierarchy of needs, the lowest demand was physical goods; the higher and highest were about psychological matter. It is also applied for everyone, and it was not surprised when someone we found with the bad appearance refuse to acknowledge that he/or she were poor. This attitude was the values or way of life as the belief of a specific culture. Therefore the sanggar wanted to convince that the important thing was the human being, with its mystery.

Another case of how to understand poverty was the past economic theory believed that the root problem of poverty was the lack of capital, but the fact showed in the last century the World Bank alone provided financial assistance to the developing countries hundreds of billions of dollar, but during 50 years had yielded the expected benefits in reducing poverty, actually in the African countries, Latin America and India.

The problem was in the people behavior, Japan was the best example. Without significant natural resources, Japan could yield agricultural product to export, while Indonesia rich in natural resources had the opposite condition.

Aids and guidance. We can have an analogy that we need others when we want to cut our hair. This example could be adopted when have a program to minimize or even to terminate poverty. We have to understand the people we want to help, therefore we are confident to recommend to involve a collaboration between inter-discipline sciences including the psychologist to solve the problem of poverty. Understand about people means the people and the environment covering as the culture, tradition, nature, values, beliefs and not limited with economic concept.

The poor where ever they existed, needed help to solve their weaknesses, the applied knowledge of how to manage their job or business and to spend their income properly.

The research found that the sanggar had the way to empower the poor since at the beginning of human life.

At last the researchers propose a theory that it is more fruitful to solve the poverty problem if it is started from understanding the poor properly to enhance capabilities by empowerment the poor with the strong reasons.

\section{REFERENCES}

1. Acemoglu, Daron \& Robinson, James A. (2012), Why Nations Fail, The Origins of Power, Prosperity and Poverty, New York: Crown Business, Random House, Inc. alihbahasa Mengapa Negara Gagal. 
2. Admassie, A. (2003), Child labour and schooling in the context of a subsistence rural economy: can they be compatible? www.elsevier.com/locate/ijedudev.

3. Amadeo, Kimberly (2019), Four Real World Ways to Create More Jobs, http://www.thebalance.com/job-creation-ideas-4-ways-that-work-best-3305521.

4. Aptekar, Lewis (1994) artikel: Street Children in the Developing World: A Review of Their Condition, Chatelaine-Geneva: LEADJournal.

5. Bakhtiar, Amsal (2014), Filsafat IImu, Jakarta: PT RajaGrafindo Persada.

6. Beazley, Harriot (2013), Voices from the Margins: Street Children's Subcultures in Indonesia, University of the Sunshine Coast Publication.

7. Beazley, Harriot, (2013), The Construction and Protection of Individual and Collective Identities by street children and Youth in Indonesia, JSTOR, http://www.jstor.org.

8. Bird, Alexander (1998), Philosophy of Science, London: University College London Press.

9. Bird, Edward J., Hagstrom, Paul A.; Wild, Robert (1999), Credit cards and the poor, Madison: University of Wisconsin, Focus Vol.20, No.2, 1999.

10. Bradshaw, Ted K (2006), Theories of Poverty and Anti-Poverty Programs in Community Development, Columbia: RUPRI Rural Poverty Research Center, http://www.rprconline.org/.

11. Brink, Barbara (2001), Working with street children: reintegration through education Support for Learning Vol. 16 No. 2 (2001).

12. Burtless, Gary; Smeeding, Timothy M. (2000), The Level, Trend, and composition of Poverty. Madison: University of Wisconsin - Madison Institute for Reseach on Poverty.

13. Cancian, Maria; Haveman, Robert; Kaplan, Thomas; Meyer, Daniel; Wolfe, Barbara (1999), Work, earnings, and well-being after welfare: What do we know, Madison: University of Wisconsin, Focus Vol.20, No.2, 1999.

14. Celik, Sevilay Senol; Baybuga, Media Subasi (2009), Verbal, physical and sexual abuse among children working on the street, Australian Journal of Advanced Nursing, Volume 26 Number 4.

15. Cohen, Carl I; Thompson, Kenneth S., (1992), Homeless Meltally III or Mentally III Homeless? Brooklyn: Health Science Center.

16. Conger, Jay A.; Kanungo, Rabindra N. (2013) The Empowerment Process: Intgrating Theory and Practice, Academy of Management Review, Vol. 13, No.3, http://www.jstor.org/stable/258093.

17. Corbett, Thomas (1999), Poverty: Improving the Measure after Thirty Years, Madison: University of Wisconsin, Focus Vol.20, No.2, 1999.

18. Corcoran, Mary, (2000), Mobility, persistence, and the intergenerational determinants of children's success, Madison: University of Wisconsin, Focus Vol.21, No.2, 2000.

19. Corcoran, Mary; Reed, Deborah (2000), Changes in family structure: I(mplications for poverty and related policy, Madison: University of Wisconsin, Focus Vol.21, No.2, 2000.

20. Creswell, John W. (2009), Research Design: Qualitative, quantitative, and mixed methods approaches, third edition, California: SAGE Publications, Inc.

21. Danziger, Sandra; Corcoran, Mary; Danziger, Sheldon; Heflin, Colleen; Kalil, Ariel; Levine, Judith; Rosen, Daniel; Seefeldt, Kristin; Tolman, Richard (1999), Barriers to work among welfare recipients, Madison: University of Wisconsin, Focus Vol.20, No.2, 1999.

22. Danziger, Sheldon H.; Haveman, Robert H. (2000), Understanding poverty: Progress and problems, Madison: University of Wisconsin, Focus Vol.21, No.2, 2000.

23. Denziger, Sheldon; Meyer, Henry J. (1999), In Pursuit of Robert J. Lampman's "modest goal": Antipoverty policy after welfare reform. Madison: University of Wisconsin, Focus Vol.20, No.2, 1999.

24. Denzin, Norman K. \& Lincoln, Yvonna S. (2009), Handbook of Qualitative Research, California: SAGE Publications, Inc.

25. Dunst, Carl J.; Trivette, Carol M.; Davis, Michelle; Cornwell, Janet, (2014) Enabling and Empowering Families of Children With Health Impairments, London: Routledge Informa Ltd http://www.tandfonlie.com/loi/hchc20. 
26. Durlauf, Steven N. (2000), The memberships theory of poverty: The role of group affiliations in determining socioeconomic outcomes, Madison: University of Wisconsin, Focus Vol.21, No.2, 2000.

27. Ed Diener, Richard, \& Shigehiro (2002), Subjective Wellbeing:The Science of Happiness and Life Satisfaction, New York: Oxford University Press.

28. Eisner, Elliot W. (2000), Benyamin Bloom, Paris: UNESCO: International Bureau of Education.

29. Fell, Ben; Hewstone, Miles (2015), Psychological Perspectives on Poverty, www.jrf.org.uk.

30. Fell, Ben; Hewstone, Miles (2015), Psychological Perspectives on Poverty, York: Joseph Rowntree Foundation, University of Oxford.

31. Freeman, Richard (2000) The rising tide lifts...?, Madison: University of Wisconsin Madison Institute for Reseach on Poverty.

32. Gale, William (2002), Income volatility and the implications for food assistance programs: Conference Papers, Madison: University of Wisconsin, Focus Vol.22, No.2, 2002.

33. Garmezy, Norman (2017), Children in Poverty: Resilence Despite Risk, http://www.tandfonlie.com/action/journalinformation/journalCode=upsy20.

34. Gillis, Malcom; Perkins, Dwight H.; Roemer, Michael; Snodgrass, Donald R (1987), Economics of Development. New York: W.W. Norton \& Company, Inc.

35. Goeltom, Miranda S. (2007), Essays in Macroeconomic Policy: The Indonesian Experience, Jakarta: PT Gramedia Pustaka Utama.

36. Graf, Gunter; Schweiger, Gottfried (2013), The philosophical evaluation of poverty, Salzburger Beiträge zur Sozialethik.

37. Green. Maia; Hulme, David (2005), From Correlates and Characteristics to Causes: Thinking About Povertyfrom a Chronic Poverty Perspective, World Development Vol.33, No.6, 2005, Elsevier Ltd.

38. Hall, Calvin S; Lindzey, Gardener (1978), Theories of Personality, New York: John Wiley \& Sons.

39. Harris, Barbara-White (2005), Destitution and the Poverty of its politics-with Special Reference to South Asia, World Development Vol. 33, No. 6, pp. 881-891, ELSEVIER, www.elsevier.com/locate/worlddev.

40. Haverman, Robert; Schwabishb (1999), Economic Growth and Poverty: A Return to Normalcy, Madison: University of Wisconsin, Focus Vol.20, No.2, 1999.

41. Herrick, Bruce; Kindleberger, Charles P., (1988) Economic Development edisi Bahasa Indonesia, Jakarta: Bina Aksara.

42. Holzer, Harry J. (1999), Will Employers hire welfare recipients?, Madison: University of Wisconsin, Focus Vol.20, No.2, 1999.

43. Honderich, Ted (1995), The Oxford Companion to Philosophy, New York: Oxford University Press, Inc.

44. Huston, Aletha C.; McLoyd, Vonnie C; Coll, Cynthia Garcia (2005), Children and Poverty: Issues in Contemporary Research, The Society for Research in Child Development, Inc.

45. Jacob, W. James; Smith, Troy D.; Hite, Steven J.; Cheng, Sheng Yao (2007), Helping Uganda's street children, http://www.tndfonline.com/loi/cjcp20.

46. Jolivet, J. (1981), Islam, Philosophy and Science, (C) Unesco 1981, alih bahasa Dodong Djiwapradja, Jakarta: PT Dunia Pustaka Jaya.

47. Jone, Gareth A., (2005), Children and Development: rights, globalization and poverty, Progress in Development Studies 5, 4(2005) pp. 136-342; Edward Arnold (Publishers) Ltd.

48. Kakwani, Nanak, (2006) Poverty and Wellbeing - International Poverty Centre, UNDP.

49. Kaplan, Thomas; Rothe, Ingrid (1999), New Hope and W-2 (Wisconsin Works): Common challenges, different responses, Madison: University of Wisconsin, Focus Vol.20, No.2, 1999.

50. Karoly, Lynn (2000), Investing in the future: Reducing poverty through human capital investment Madison: University of Wisconsin, Focus Vol.21, No.2, 2000. 
51. Kasali, Rhenald (2007) Re-Code, YourChange DNA, Jakarta: PT Gramedia Pustaka Utama.

52. Khan, Mahmood Hasan (2000), Rural Poverty in Developing Countries: Issues and Policies, IMF Working paper.

53. Krecker, Margaret L; Brown, Patricia; Melli, Marygold S.; Wimer, Lynn (2002), Children's living arrangements after divorce: How stable is joint physical custody, IRP Special Report, Madison: University of Wisconsin, Focus Vol.22, No.2, 2002.

54. Lam, Debbie; Cheng Fucai (2008), Chinese Policy reaction to the problem of street children: An analysis from the perspective of street children, ELSEVIER, www.elsevier.com/locate/childyouth.

55. le Roux, Johann (1996), The Worlwide Phenomenon of Street Children: Conceptual Analysis, San Diego: ADOLESCENCE, Vol. 31, No. 124, Libra Publishers, Inc.

56. Lord, John; Hutchison, Peggy (1993), The Process of Empowerment: Implications for Theory and Practice, Canadian Journal of Community Mental Health 12:1, Spring 1993.

57. Loury, Glenn C., (2000) Povety and Race, Madison: University of Wisconsin, Focus Vol.21, No.2, 2000.

58. Maforah, Fidelia (1994), The Impact of Poverty on Health in Urbanising Communities, Michigan State University Libraries.

59. Mardiman, Yohanes (1996) Kritis Proses Pembangunan di Indonesia, Yogyakarta: Penerbit Kanisius.

60. Mawardi, Sulton et al (2006). Moving Out of Poverty: The Case of Gura, Kabupaten Halmahera Utara, Jakarta: The SMERU Research Institute.

61. Maxwell, Simon (1999), The Meaning and Measurement of Poverty, London: Overseas Development Institute.

62. Max Weber (2012), The Sociology of Religion, edisi Bahasa Indonesia, Yogyakarta: IRCiSoD.

63. McKay, Andrew (2007), Combining Quantitative and Qualitative Methods in Assessing Chronic Poverty: The Case of Rwanda, World Development Vol.35, No.2, 2007, Elsevier Ltd.

64. Milton \& Rose, Friedman (2013), Free to Choose, edisi Bahasa Indonesia, Yogyakarta: Pustaka Pelajar

65. Monteiro, Julieta M. Campos; Dollinger, Stephen J., (1998), An Autophotographic Study of Poverty, Collective Orientation, and Identity Among Street Children, London: Routledge Informa Ltd, http://www.tandfonlie.com/loi/vsoc20.

66. Murnane, Richard J. (2007), Improving the Education of Children Living in Poverty, Questia, https://www.questia.com/read/1G1-179425332/improving-the educa.

67. Newman, Katherine S. (2002), The right (soft)stuff: Qualitative methods and the study of welfare reform, Madison: University of Wisconsin, Focus Vol.22, No.2, 2002.

68. Nieuwenhuys, Olga, (1995) Action research with street children: a role for street educators, PLA Notes CD-ROM 1988-2001, Issue 25, pp. 52-55, IIED London.

69. Panter-Brick, Catherine (2002), Street Children, Human Rights, and Public Health: A Critique and Future Directions, University of South Dakota, www.annualreviews.org.

70. Panter-Brick, Catherine, (2004), Homelessness, poverty, and risks to health: beyond at risk categorizations of street children, London: Routledge Informa Ltd http://www.tandfonlie.com/loi/cchg20.

71. Pavetti, LaDonna (1999), How much more can welfare mothers work, Madison: University of Wisconsin, Focus Vol.20, No.2, 1999.

72. Pavetti, LaDonna (2000), Welfare policy in transition: Redefining the social contract for poor citizen families with children, Madison: University of Wisconsin, Focus Vol.21, No.2, 2000.

73. Perkins, Douglas D.; Zimmerman, Marc A. (1995), Empowerment Theory, Research, and Applications, American Journal of Community Psychology, Vol. 23, No.5, 1995.

74. Pettit, Jethro (2012), Empowerment and Participation: bridging the gap between understanding and practice, New York: United Nations Headquarters, UN Department of Economic and Social Affairs, Division for Social Policy and Development. 
75. Radelet, Steven (2015), the Great Surge, New York: Simon \& Schuster.

76. Rafi, Sadia et al (2012), The Problem of Street Children: Case Study of Sargodha City, American International Journal of Contemporary Research Vol.2 No.2, February 2012.

77. Robbins, Lord (1968), The Theory of Economic Development in the History of Economic Thoughts, London: Macmillan and Co., Ltd.

78. Sachs, Jeffrey D. (2014). The End of Poverty, London: Penguin Books Ltd.

79. Sampson Jr, James P. (2012), A Guide to Quantitative and Qualitative Dissertation Research, College of Education Florida State University.

80. Samuelson, Paul A.; Nordhaus, William D. (1989), Economics, Singapore: McGraw Hill Book Co.

81. Schweiger et al.(2015), A Philosophical Examination of Social Justice and Child Poverty (C) Gottfried Schweiger and Gunter Graf.

82. Shah, Anup (2011) Poverty Around The World, Global Issues http://www.globalissues.org

83. Siahaan, Hotman (2011) Poverty in Surabaya: A Phenomenological Analysis, Surabaya: Universitas Airlangga, Departemen Sosiologi, FISIP.

84. Strauss, Anselm; Corbin, Juliet (2015), Basics to Qualitative Research, edisi bahasa Indonesia Dasar-dasar Penelitian Kualitatif, Yogyakarta: Pustakapelajar.

85. Suwarjuwono, Tjiptohadi (2012), Workshop of qualitative method guidance, Surabaya: Ikatan Akuntan Indonesia Wilayah Jatim \& FEB Airlangga University.

86. Suyanto, Bagong (2013), Anatomy of Poverty, Malang: Intrans Publishing.

87. Taylor, Steven J.; Bogdan, Robert; De Vault, Marjorie (1992), Introduction to Qualitative Research Methods: A Guidebook and Resource. John Wiley \& Sons, Inc.

88. Todaro, Michael P (2012), Pembangunan Ekonomi di Dunia Ketiga, Jakarta: Penerbit Erlangga.

89. Townsend, Peter (1979), Poverty in the United Kingdom, Middlesex: Penguin Books Ltd, Harmondsworth.

90. Volpi, Elena, (2002), Street Children: Promising Practices and Approaches, Washington: The International Bank for Reconsctruction and Development/The World Bank.

91. Waldfogel, Jane (2000) Poverty and children Madison: University of Wisconsin, Focus Vol.21, No.2, 2000.

92. Western, Bruce (2001), Incarceration, employment, and inequality, Madison: University of Wisconsin, Focus Vol.21, No.3, 2001.

93. Wu, Lawrence; Wolfe, Barbara (2001), Out of Wedlock: Causes and Consequences of Nonmarital Fertility, Madison: University of Wisconsin, Focus Vol.21, No.3, 2001.

94. Ziliak, James P. (2002), Social Policy and the macroeconomy: What drives welfare caseloads? Madison: University of Wisconsin, Focus Vol.22, No.1, 2002. 